\title{
Histomorfometri Sel Darah Putih Agranulosit Bibit Sapi Bali di Nusa Penida
}

\section{(HISTOMORPHOMETRY OF AGRANULOCYTE WHITE BLOOD CELLS OF BALI CATTLE IN NUSA PENIDA)}

\author{
M. Oenas Adinugroho', Ni Ketut Suwiti ${ }^{2}$, Anak Agung Sagung Kendran² \\ ${ }^{1}$ Mahasiswa Fakultas Kedokteran Hewan Universitas Udayana. ${ }^{2}$ Laboratorium Histologi \\ Veteriner Universitas Udayana, Jl. P.B. Sudirman Denpasar-Bali \\ Email:mario.onaz@gmail.com
}

\begin{abstract}
ABSTRAK
Penelitian ini bertujuan untuk mengetahui struktur histologi dan morfometri sel darah putih agranulosit (limfosit dan monosit) bibit sapi bali di Nusa Penida. Sampel berupa darah dari 50 ekor sapi bali betina, diambil melalui vena jugularis. Selanjutnya difiksasi, dan diwarnai dengan metode pewarnaan Giemza. Pengukuran morfometri dilakukan dengan mikroskop Axio Zeiss Imager 2 perbesaran 1000x. Hasil pengukuran dianalisis secara deskriptif kuantitatif, sedangkan gambaran histologi dianalisis dengan deskriptif kualitatif. Hasil penelitian menunjukkan rerata diameter limfosit $(9,22 \pm 0,73 \mu \mathrm{m})$ lebih kecil dibandingkan dengan monosit $(12,48 \pm 1,73 \mu \mathrm{m})$. Adanya perbedaan struktur histologi limfosit dan monosit, yang ditemukan pada nukleusnya. Nukleus limfosit, bulat dan memenuhi sitoplasma, sedangkan nukleus monosit membentuk lekukan pada satu atau dua sisinya, sehingga tidak memenuhi sitoplasma dari sel.
\end{abstract}

Kata kunci: sapi bali; Nusa Penida; limfosit; monosit; histologi; histomorfometri

\section{ABSTRACT}

This study aims to determine about the histology structure and the morphometry white blood cells agranulocytes (lymphocytes and monocytes) of Bali cattle in Nusa Penida. A sample of blood from 50 female calves, had been taken through a jugular vein. The blood samples were fixed and colored by using Giemza staining method. The morphometry measurement was performed with was done under Axio Zeiss Imager 2 microscope with 1000x magnification. The results of the measurements were analyzed descriptively quantitatively, while the histology description was analyzed by qualitative descriptive. The results showed average mean lymphocyte diameter $(9.22 \pm 0.73 \mu \mathrm{m})$ was smaller than monocytes $(12.48 \pm 1.73 \mu \mathrm{m})$. The existence of the lymphocyte and monocytes histologic structure difference which are found in the nucleus. The lymphocyte nucleus was round and filled the cytoplasm, whereas the monocyte nucleus formed a curve on one or two sides, thus, it did not fill the cytoplasm.

Keywords: bali cattle; Nusa Penida; lymphocyte; monocyte; histology; histomorphometry

\section{PENDAHULUAN}

Di Indonesia ditemukan empat kelompok sapi asli yakni: sapi aceh, sapi pesisir, sapi madura dan sapi bali. Sapi aceh terdapat di Nanggroe Aceh Darussalam, sapi pesisir di Sumatera Barat, sapi javaongole di pulau Jawa, sapi bali di Pulau Bali, dan sapi madura di Pulau Madura (Martojo, 2003). Sapi bali merupakan sumber daya genetik asli Indonesia yang penting dan terdapat dalam jumlah yang cukup besar. Sapi bali bukan hanya terdapat di Bali melainkan telah menyebar di seluruh Indonesia, seperti Nusa Tenggara Barat (NTB), Nusa Tenggara Timur (NTT), Kalimantan, Sulawesi, dan Jawa Timur. Keunggulan sapi bali dibandingkan sapi lain adalah memiliki sifat reproduksi dan kualitas karkas sangat baik, tahan pada kondisi lingkungan tropis dan pakan yang buruk, serta mempunyai fertilitas yang tinggi (Supriyantono et al., 2008).

Nusa Penida ditetapkan sebagai pusat pembibitan dan pemurnian sapi bali 
sehingga Nusa Penida dikatakan sebagai "pure breed" yang patut dijaga kemurniannya. Alasan utama pulau ini dipilih sebagai pusat pembibitan dan pemurnian disebabkan bebas dari penyakit, seperti Jembrana, penyakit mulut dan kuku, antraks dan MCF serta faktor pendukung lainya. Selain itu, nilai produksi tinggi, kualitas daging yang sangat baik dan menghasilkan vaksin penyakit Jembrana juga merupakan faktor penting (Kasa et al., 2015).

Diharapkan dengan penentuan pulau Nusa Penida sebagai wilayah sumber bibit sapi bali melalui kegiatan pengembangan pembibitan sapi bali di Nusa Penida, akan menjadi momentum untuk mengakselerasi terwujudnya upaya pengembangan dan peningkatan mutu bibit sapi bali. Bibit sapi bali yang unggul akan diberikan Surat Keterangan Layak Bibit (SKLB). Kriteria penilaian SKLB hanya berdasarkan fenotipik dan ukuran eksterior saja, sehingga belum memberikan informasi secara lengkap.

Oleh karena itu perlu dilakukan identifikasi lain yakni dengan melakukan pengamatan histologi dan morfometri sel darah putih (leukosit). Leukosit diketahui berperan dalam kekebalan tubuh atau imunitas sapi bali, untuk menghindarkan sapi bali terhadap penyakit infeksius. Peningkatan dan penurunan jumlah leukosit dapat terjadi karena faktor fisiologis atau patologis (Linda et al., 2014).

Leukosit dapat dibagi menjadi dua kategori yaitu granulosit dan agranulosit. Granulosit adalah sel yang memiliki segmen atau lobus pada inti sel dan granul pada sitoplasma, terdiri atas neutrofil, basofil, dan eosinofil. Agranulosit adalah sel yang tidak memiliki segmen atau lobus pada inti dan tidak ada granul pada sitoplasma, terdiri atas limfosit dan monosit. Limfosit berupa sel bulat kecil berdiameter 7-12 $\mu \mathrm{m}$, memiliki nukleus yang relatif besar, berbentuk bulat atau sedikit berlekuk, yang dikelilingi oleh sitoplasma. Fungsi utama limfosit sebagai respon terhadap adanya antigen dengan cara membentuk antibodi yang bersirkulasi di dalam darah atau dalam pengembangan imunitas seluler (Junqueira dan Caneiro, 2005). Selnya bulat berdiameter 9-12 $\mu \mathrm{m}$ dalam larutan, tetapi pada apusan darah kering, berdiameter sampai $17 \mu \mathrm{m}$. Monosit berperan sebagai prekursor untuk makrofag, dan sel ini akan mencerna dan membaca antigen (Lokapirnasari dan Yulianto, 2014).

Leukosit agranulosit dan granulosit diketahui dapat berubah baik dalam hal struktur histologi maupun ukurannya (morfometri). Pemeriksaan histomorfometri dapat digunakan untuk mengamati kelainan pada sel darah. Beberapa penelitian tentang morfometri telah dilakukan, sedangkan histomorfometri leukosit agranulosit pada bibit sapi bali di Nusa Penida belum pernah dilakukan. Penelitian ini menjadi penting mengingat Nusa Penida mempunyai karakteristik geografis yang sangat khusus, sehingga dapat berpengaruh terhadap sapi bali yang dipelihara disana khususnya gambaran histomorfometri agranulosit.

\section{METODE PENELITIAN}

\section{Materi Penelitian}

Sampel berupa darah bibit sapi bali sebanyak 50 ekor yang dipelihara di Nusa Penida, kemudian dibuat apusan darah. Bahan untuk membuat apusan darah adalah methyl alkohol absolut (metanol absolut), pewarna Giemza, alkohol, aquadest, dan minyak Emersi. Alat-alat yang digunakan berupa: venoject, gelas obyek, gelas fiksasi (coplin jar), gelas beaker, rak pewarna, mikroskop, dan komputer.

\section{Metode Penelitian}

Penelitian ini merupakan penelitian eksploratif dengan menggunakan penelitian deskriptif kualitatif dan kuantitatif. Penelitian ini dilakukan untuk mengukur sel darah putih agranulosit bibit sapi bali di Nusa Penida. Sampel darah diambil dari sapi bali betina (bibit) melalui vena jugularis dengan menggunakan venoject, lalu dibuat apusan darah. Pembuatan dan fiksasi apusan darah. Metode yang 
digunakan dalam pembuatan sampel apusan darah yaitu dengan metode slide. Sedangkan proses pewarnaan Giemza serta pemeriksaan histologi dan histomorfometri dilakukan mengikuti metode yang dilakukan oleh (Lestari et al., 2013).

Pengukuran sel darah putih dilakukan di bawah mikroskop dengan pembesaran lensa obyektif 100x dan lensa okuler 10x dibantu dengan meneteskan minyak Emersi untuk mengurangi adanya bias (Rahayu et al., 2016). Pengamatan pengukuran sel darah putih agranulosit menggunakan mikroskop Axio Imager Zeiss 2 dan software ZEN 2012. Pengamatan preparat ulas darah dimulai dari ujung preparat dan bergerak ke sisi selanjutnya, lalu berpindah sejauh 2 sampai 3 lapang pandang dengan menggunakan battlement metode. Setelah mendapatkan leukosit yang dimaksud lakukan tangkapan layar dengan melakukan klik "Snap" pada program ZEN 2012. Setelah gambar berhasil ditangkap maka pengukuran diameter dilakukan dengan menjalankan perintah pada menu bar yaitu klik "Graphic" kemudian pilih "Circle Diameter" dengan cara membuat lingkaran dengan kursor mouse pada sel darah putih agranulosit yang telah ditemukan, maka akan mendapatkan hasil dari diameter sel darah putih agranulosit tersebut secara otomatis.

\section{Analisis Data}

Struktur histologi sel darah putih agranulosit dianalisis secara kualitatif dan ukuran diameter sel darah putih agranulosit disajikan secara deskriptif kuantitatif dengan program SPSS versi 16.

\section{HASIL DAN PEMBAHASAN}

Struktur histologi leukosit agranulosit bibit sapi bali di Nusa Penida yang terdiri dari limfosit dan monosit menunjukkan adanya berbagai variasi secara histologi. Variasi limfosit ditemukan pada bentuk dengan perbedaan penyerapan warna tidak terlalu spesifik. Nukleus berbentuk bulat dan padat, besarnya hampir memenuhi seluruh sehingga sel sitoplasmanya tidak terlalu terlihat jelas (Gambar 1a). Bahkan ada yang memenuhi seluruh sel sehingga sitoplasma tidak terlihat (Gambar 1b). Perbedaannya terletak pada nukleus yang bentuknya tidak bulat penuh sampai terlihat tidak beraturan. Struktur histologi limfosit sapi bali di Nusa Penida secara umum sama dengan limfosit pada hewan lainnya.

Struktur histologi limfosit memiliki inti yang besar, dimana sel hampir menutupi seluruh sel dan memiliki sitoplasma yang tipis. Pada sediaan ulas darah sitoplasmanya berwarna pucat (Junqueira dan Caneiro, 2005). Bentuk limfosit bulat dan berisi inti yang bulat besar dengan kromatin yang padat. Hal ini disebabkan limfosit ada limfosit besar dan limfosit kecil, limfosit besar memiliki sitoplasma yang tebal dibandingkan dengan limfosit kecil (Tadjalli, 2013).

Struktur histologi monosit sapi bali di Nusa Penida (Gambar 2) ditemukan beberapa perbedaan diantaranya memiliki bentuk sel menyerupai kacang dengan bentuk nukleus padat. Sitoplasma terlihat jelas mengelilingi nukleus sehingga terlihat bulat penuh (Gambar 2a). Berbeda dengan monosit (Gambar 2b) yang memiliki nukleus dengan lekukannya yang lebih dalam dengan bentukan antar segmen sedikit menjauh dan terlihat tidak simetris, tidak padat dan terlihat sitoplasmanya. Terlihat segmen nukleus bagian atas terlihat lebih besar dibandingkan segmen pada bagian bawah. Selain itu selnya juga terlihat bulat dan memiliki sitoplasma yang tidak terlihat jelas (Gambar 2b). Bentuk nukleus monosit (Gambar 2c) lebih variatif jika dibandingkan dengan monosit pada (Gambar 2a) dan (Gambar 2b). Nukleusnya berbentuk seperti angka "8" (Gambar 2c) yaitu memiliki lekukan pada kedua sisi nukleus. Sitoplasma terlihat jelas pada monosit bibit sapi bali di Nusa Penida ini dengan bentuk yang bulat penuh dan mengelilingi nukleus. Selain hal tersebut diatas bentuk monosit sapi bali di Nusa Penida secara umum sama dengan monosit pada hewan lainnya. 
Sitoplasma monosit tidak memiliki granular, bentuk menyerupai huruf " $U$ " atau berbentuk seperti ginjal, sehingga sitoplasmanya relatif lebih banyak dibandingkan dengan limfosit dengan warna kebiruan sedikit pucat. Inti monosit

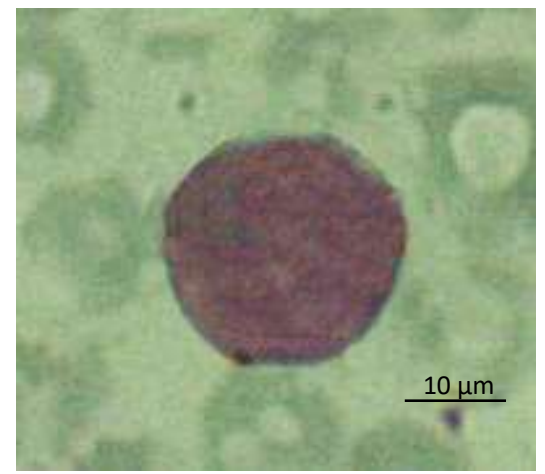

A memiliki berbagai bentuk yang berbeda (pleomorfik), tetapi tidak membentuk segmen. Apabila dibandingkan dengan limfosit nukleus monosit memiliki warna yang lebih pucat dari limfosit dengan sitoplasma lebih banyak.

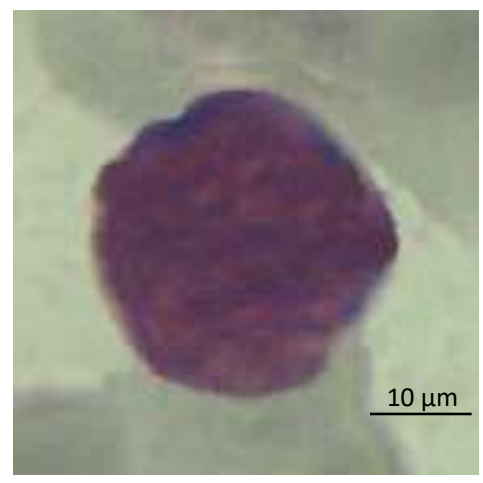

B

Gambar 1. Struktur Histologi Limfosit Bibit Sapi Bali di Nusa Penida

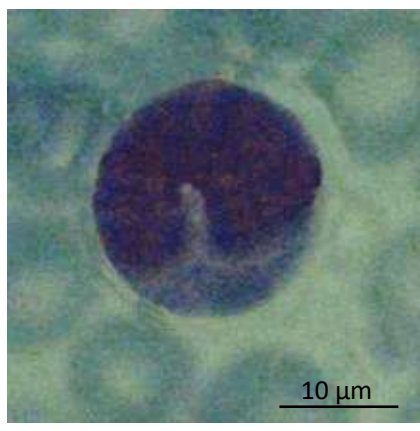

A

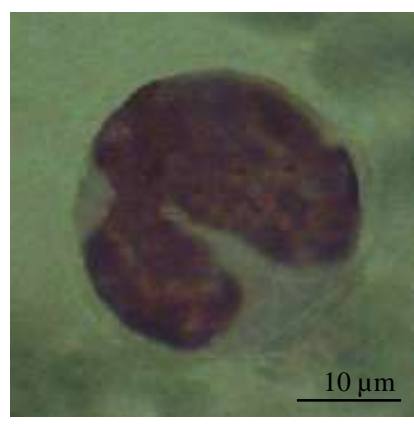

B

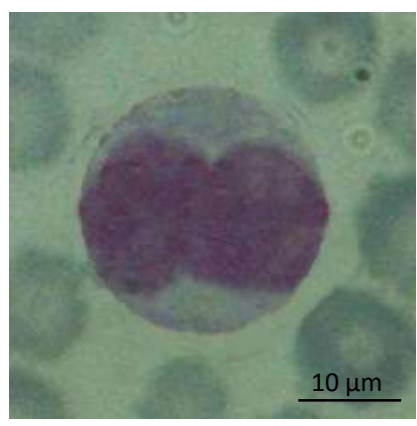

C

Gambar 2. Struktur Histologi Monosit Bibit Sapi Bali di Nusa Penida

\section{Morfometri Limfosit dan Monosit}

Rerata diameter limfosit: 9,225124 $\mu \mathrm{m}$, diameter terkecil adalah 7,096 $\mu \mathrm{m}$ sedangkan terbesar: 11,836 $\mu \mathrm{m}$ (Tabel 1). Pada sediaan ulas darah yang diwarnai dapat dibedakan adanya limfosit besar dan limfosit kecil. Limfosit kecil berdiameter 6$9 \mu \mathrm{m}$, inti besar dan kuat mengambil zat warna, dikelilingi sedikit sitoplasma yang berwarna biru pucat, sedangkan limfosit besar berukuran 12-15 $\mu \mathrm{m}$, memiliki lebih banyak sitoplasma, dan inti lebih besar dan sedikit pucat dibandingkan dengan limfosit kecil (Junqueira dan Caneiro, 2005).
Apabila dibandingkan dengan hewan lainnya seperti kucing, ukuran limfosit ditemukan lebih kecil, yakni 8,7-14,5 $\mu \mathrm{m}$. Ukuran tersebut dibagi menjadi 3 yaitu, kecil, sedang, dan besar tergantung pada rasio sitoplasma nukleus. Ukuran dari limfosit kecil 8,7 $\mu \mathrm{m}$, limfosit sedang 10,9 $\mu \mathrm{m}$, limfosit besar $14,5 \mu \mathrm{m}$. Sel-selnya berbentuk bulat dengan inti oval dengan sitoplasma berwarna biru muda (Prihirunkit et al., 2007).Tidak terlalu berbeda dengan anjing yang memiliki diameter limfosit 8,42-14,67 $\mu \mathrm{m}$ dengan sitoplasma berwarna biru pucat dan kadang-kadang limfosit memiliki butir azurofilik kecil dalam sitoplasma (Salakij et al., 2000). Menurut 
Marshall (2008), ukuran diameter limfosit pada kelinci didapat 7-15 $\mu \mathrm{m}$. Limfosit pada landak juga pernah diukur diameternya dan didapatkan hasil rataan yaitu 8,5 $\mu \mathrm{m}$ (Sinambela, 2012).

Diameter monosit sapi bali di Nusa Penida adalah 12,48413 $\mu \mathrm{m}$, terkecil adalah $8,417 \mu \mathrm{m}$ dan ukuran terbesarnya adalah 21,621 $\mu \mathrm{m}$. Rerata diameter monosit pada kucing adalah $13,8 \mu \mathrm{m}$. Intinya sangat bervariasi, ada yang berbentuk bulat, lobus ganda atau berbentuk pita, tetapi biasanya menjorok ke dalam dan berenda pada kromatinnya. Sitoplasmanya sedang sampai berlimpah dengan warna biru keabu-abuan (Prihirunkit et al., 2007). Pada anjing ukuran diameter monosit bervariasi yaitu 12-17 $\mu \mathrm{m}$ dengan rata-rata $14 \mu \mathrm{m}$ (Salakij et al., 2000). Pada kelinci memiliki diameter 15-18 $\mu \mathrm{m}$. Monosit memiliki inti amuboid, kromatin inti menyebar, dan sitoplasma biru (Marshall, 2008). Ukuran monosit landak memiliki diameter $10,5 \mu \mathrm{m}$ (Sinambela, 2012).

Ukuran tersebut jika dibandingkan dengan monosit kucing memiliki ukuran yang lebih kecil. Jika dibandingkan dengan monosit pada anjing monosit pada sapi bali di Nusa Penida lebih kecil. Begitu pula jika dibandingkan dengan ukuran diameter monosit pada kelinci, maka monosit bibit sapi bali di Nusa Penida juga berukuran lebih kecil. Monosit sapi bali di Nusa Penida hanya memiliki ukuran lebih besar apabila dibandingkan dengan ukuran monosit pada landak. Monosit merupakan jenis leukosit berukuran paling besar diantara semua jenis leukosit dengan ukuran 15-20 $\mu \mathrm{m}$ dan berjumlah 3-9\% dari total leukosit. Monosit memiliki inti sel seperti biji kacang, dan sitoplasma tampak biru keabu-abuan dengan pewarnaan Giemza (Peckham, 2014).

Tabel 1. Diameter limfosit dan monosit sapi bali di Nusa Penida

\begin{tabular}{lllll}
\hline Leukosit & Rerata $(\mu \mathrm{m})$ & Minimum $(\mu \mathrm{m})$ & Maximum $(\mu \mathrm{m})$ & Std. Deviasi \\
\hline Monosit & 12.484132 & 8.417 & 21.621 & 1.730993 \\
Limfosit & 9.225124 & 7.096 & 11.836 & 0.731792 \\
\hline
\end{tabular}

Limfosit dan monosit sapi bali di Nusa Penida memiliki ukuran yang lebih kecil jika dibandingkan dengan ukuran limfosit dan monosit pada kucing, anjing, dan kelinci. Namun ukuran limfosit dan monosit lebih besar pada sapi bali di Nusa Penida jika dibandingkan dengan ukuran monosit landak. Hal tersebut diatas bisa disebabkan karena spesies yang berbeda. Penelitian histomorfometri limfosit dan monosit bibit sapi bali di Nusa Penida tidak bisa dibandingkan dengan limfosit dan monosit sapi bali diluar wilayah tersebut karena keterbatasan informasi yang dipublikasikan.

\section{SIMPULAN DAN SARAN}

\section{Simpulan}

Struktur histologi limfosit dan monosit bibit sapi bali di NusaPenida memiliki bentuk nukleus yang bervariasi. Pada limfosit ditemukan bentuk nukleus bulat namun tidak beraturan, sedangkan monosit bentuk nukelus mempunyai lekukan pada satu/dua sisinya. Diameter limfosit $(9,22 \pm 0,73 \mu \mathrm{m})$ lebih kecil dibandingkan dengan monosit $(12,48 \pm 1,73 \mu \mathrm{m})$.

\section{Saran}

Perlu dilakukan penelitian dengan membandingkan leukosit sapi bali yang dipelihara di daerah lainnnya.

\section{UCAPAN TERIMAKASIH}

Pada kesempatan ini penulis mengucapkan terimakasih kepada peternak di Nusa Penida, dan Pemerintah Disnak Keswan Kabupaten Klungkung atas izin dan kerjasamanya, sehingga penelitian ini dapat terlaksana.

\section{DAFTAR PUSTAKA}

Arifin Z. 2008. Beberapa unsur mineral sensial mikro dalam sistem biologi dan 
metode analisisnya. J. Litbang. Pertanian, 27(3): 99-105.

Dharma WA, Sudaryat S, Aryasa KN, Suandi IKG. 2005. Peran suplementasi mineral mikro seng terhadap peran suplementasi mineral mikro seng terhadap kesembuhan diare. Sari Pediatri, 7(1): 15-18.

Junqueira LC, Caneiro J. 2005. Basic Histology Text and Atlas. Ed ke-11. USA: The Mc Graw-Hill Companies Inc.

Kasa IW, Sukmaningsih AAS, Darmayasa IB. 2015. Efforts in conserving purebred bali cattle as draught and beef type in Bali island, Indonesia. Buletin Veteriner Udayana, 7(1): 95-100.

Lestari SHA, Ismoyowati, Indradji M. 2013. Kajian jumlah leukosit dan differensial leukosit pada berbagai jenis itik lokal betina yang pakannya di suplementasi probiotik. J. Ilmiah Peternakan, 1(2): 699709.

Linda, Ramadhan A, Tureni D. 2014. Pengaruh ekstrak biji pala (Myristica fragrans) terhadap jumlah eritrosit dan leukosit pada tikus putih (Rattus norvegicus). E-Jipbiol., 3: 1-8.

Lokapirnasari WP, Yulianto AB. 2014. Gambaran sel eosinofil, monosit, dan basofil setelah pemberian spirulina pada ayam yang diinfeksi virus flu burung. J. Vet., 15(4): 499-505.

Marshall KL. 2008. Rabbit hematology. Veterinary Clinics of North America: Exotic Animal Practice, 11(3): 551567.

Martojo H. 2012. Indigenous Bali cattle is most suitable for sustainable small farming in Indonesia. Reprod. Domest. Anim., 47(1): 10-14.
Rahayu N, Suwiti NK, Suastika P. 2016. Struktur histologi dan histomorfometri granulosit pada sapi bali pasca pemberian mineral. Buletin Veteriner Udayana, 8(2): 151-158.

Prihirunkit K, Salakij C, Apibal S, Narkkong NA. 2007. Hematology, cytochemistry and ultrastructure of blood cells in fishing cat(Felis viverrina). J. Vet. Sci.,. 8(2): 163-168.

Putra IPC, Suwiti NK, Ardana IBK. 2016. Suplementasi mineral pada pakan sapi bali terhadap diferensial leukosit di empat tipe lahan. Buletin Veteriner Udayana, 8(1): 8-16.

Salakij C, Salakij J, Rattanakunuprakarn J, Tengchaisri N, Tunwattana W, Apibal S. 2000. Morphology and cytochemistry of blood cells from asian wild dog (Cuon alpinus). Kasetsart J. Nat. Sci., 34(4): 518-525.

Sinambela EM. 2012. Studi hematologi pada landak jawa (Hystrix javanica). Skripsi. Fakultas Kedokteran Hewan Institut Pertanian Bogor.

Supriyantono A, Lukman H, Suyadi, Ismudiono. 2008. Performansi sapi bali pada tiga daerah di Provinsi Bali. Berk. Panel. Hayati, 13: 147-152.

Suwiti NK, Putra S, Puja N, Watiniasih NL. 2012. Peningkatan produksi sapi bali unggul melalui pengembangan model peternakan terintegrasi. Laporan Penelitian Prioritas Nasional (MP3EI) Tahap I. Pusat Kajian Sapi Bali Universitas Udayana.

Tadjali M, Nazifi S, Abbasabadi BM, Majidi B. 2013. Histomorphometric study on blood cell in male adult ostrich. Vet. Res. Forum, 4(3): 199-203. 